\title{
Editorial
}

\section{Is WHO ineffectual because its members are ministries not states?}

Journal of Public Health Policy (20I 5) 36, I3 I-I33. doi:I0.1057/jphp.20I 5.4; published online I9 February 2015

Its reputation damaged by its poor performance against Ebola, the World Health Organization seems to want to respond more effectively to public health emergencies. Buried, however, in a New York Times story about a January 20I 5 meeting in Geneva of the WHO Executive Board and its decision to upgrade the United Nations agency's emergency response capacity was a key sentence: “These steps were all recommended but not put in place after a review of the response to the

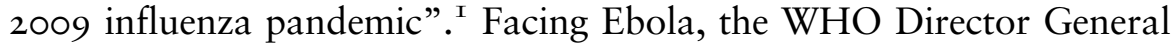
had said, "We are not the first responder".

The WHO seems aware how poorly it performed then. "Did it have to happen this way?", asked Yvette Stevens, a representative from Sierra Leone, reading the country's statement to participants at the meeting in Geneva and referring to the large death toll from Ebola, which many viewed as avoidable with better preparedness. "There needs to be a system in place to react in a more effective and timely way". ${ }^{\mathrm{I}}$ How could these countries have been better prepared, and the global community more effective in supporting them?

Nobelist Joshua Lederberg and infectious diseases specialists worldwide have often reminded us of the inevitability of a next crisis of contagion. Influenza and Ebola come from a long and dangerous list of possibilities for what may come next. Why, then, do so many seem so surprised each time the inevitable next crisis comes to pass?

It appears that the key issue in front of the January $2015 \mathrm{WHO}$ Executive Board was how to capture more resources for emergency responses, and quickly. But even countries with an abundance of resources had failed to act quickly enough. The response from Cuba, for example, was initially faster and more robust than that from the United States. 
Dr Frieden, Director of the US Centers for Disease Control, must grasp the irony in his situation. In the last decade, his country has invested trillions of dollars in preparing for and fighting wars. Yet while he was head of its national public health agency, his country failed to evince appropriate concern and contribute sufficient resources for the campaign against Ebola. As in other countries, US health officials lacked the clout to lead. They failed to inspire their governments to adequate action.

We have often joked with and corrected colleagues who talked about WHO's 194 'member states', when, in fact, WHO has I94 'member ministries of health'. There's the rub. In every country the ministry of health remains one of the least powerful ministries, surely well below finance, defense, foreign affairs, and often others. Why should we expect that the global organization whose members are these weak ministries could effectively drive the actions of I 94 'member states'?

The countries that now face Ebola have never fully recovered from colonialism, military leadership, and poverty. To put Ebola in perspective, these countries still have more maternal and perinatal deaths from malaria than from Ebola. The entire country of Liberia has fewer doctors (about 200, some of whom died of Ebola) than the one hospital in New York City (about I 500) that mobilized to treat a single US physician returning from Liberia with Ebola.

Perhaps Dr Chan, the WHO's Director General, has belatedly seen the light. She has called for international support to increase WHO's capacity to respond to emergencies. Her new request appears to have been triggered by suggestions that new and better financed organizations take on parts of WHO's mission. In addressing the WHO Executive Board in January, she eventually came out with a vision for the future:

We need to stop thinking about core capacities as something that should be tacked onto a country's health systems, like an extra arm. No. The capacities needed to undertake sensitive surveillance, provide laboratory support, manage data collection and reporting, and mount a response need to be an integral part of the health system. Well-functioning health systems are not a luxury. They are the cushion that keeps sudden shocks from reverberating throughout the fabric that holds societies together, ripping them apart. This is one of the biggest lessons the world learned last year. ${ }^{2}$ [Editor's Note: Why did it take until last year and did the world really learn it?]

I32 (C) 2015 Macmillan Publishers Ltd. OI97-5897 Journal of Public Health Policy Vol. 36, 2, I3 I-I33 
Can WHO, its health ministers, and their allies teach the world that no one will cope with crises effectively if every day public health challenges suffer from scarcity and neglect?

Every time a country chooses to buy a new Mirage or F-I 6 fighter aircraft before training a new nurse or building a new water system, who will tell the world that the country is opting for a new epidemic for its population (and not just the war it is preparing to fight)?

Even after her compelling speech to the Executive Board, we doubt that the current Director General retains sufficient credibility worldwide to lead a campaign for global public health preparedness. Will public health leaders around the world, most importantly courageous ministers of health, take the lead to strengthen WHO and find ways to engage the entirety of their governments? No one doubts that critical expertise resides at WHO. But we need a WHO that can, as part of a broader alliance, influence governments and powerful non-health ministries to invest in functional health systems.

We hope the World Bank and other organizations that might help pay for preparedness will not abandon WHO's potential for public health leadership. Surely WHO's weaknesses are known to the Bank's President, Dr Kim, who has first-hand knowledge of the institution from the inside as well as from his position at the Bank. Reform and strengthening of WHO needs to address priorities country by country, emphasizing that only with resilient public health systems everywhere can crises be managed effectively.

Before creating another opaque finance entity steeped in money, not public health, to pay for preparedness, can we not support the belated call for reform to make WHO effective?

\section{References}

I. Fink, S. (2015) W.H.O. members endorse resolution to improve response to health emergencies, New York Times 25 January, http:/www.nytimes.com/2015/oI/26/world/who-members-endorseresolution-to-improve-response-to-health-emergencies.html?_r=o, accessed 29 January 20 I 5.

2. Chan, M. (2015) Dr Margaret Chan address at the Executive Board Meeting - 25 January, Geneva, Switzerland, http://www.cadureso.com/actualite/actualite-sante/5887-dr-margaretchan-address-at-the-executive-board-meeting-25-january-20 I 5, accessed 3 I January 20 I 5 .

Anthony Robbins and Phyllis Freeman Co-Editors, E-mail: jphp@umb.edu 